\title{
Extracurricular Activities Influencing Academic Performance of Undergraduate Medical Students of Bangladesh: Teachers' and Students' Views
}

\author{
Dr. Arifa Begum ${ }^{1}$, Prof. Dr. AKM Asaduzzaman ${ }^{2}$, Prof. Dr. Md. Humayun Kabir Talukder, \\ Dr. Md. Shakil Hossan ${ }^{4}$, Dr.Syeda Mahmuda Akhter ${ }^{5}$
}

\begin{abstract}
This descriptive cross sectional study was conducted to identify the teachers' \& students' views according to extracurricular activities influencing academic performance of undergraduate medical students. The study period was July 2017 to June 2018. The study was carried out among four phases of undergraduate medical students \& teachers of basic science, para clinical $\&$ clinical subjects of four (04) government \& four (04) non-government selected medical colleges of Dhaka \& outside Dhaka. Medical colleges were selected purposively \& convenience sampling technique was adopted for data collection. A self-administered semistructured questionnaire using five points Likert scale were administered on 58 teachers \& 1020 students to collect data \& an interview schedule was used to conduct in-depth interviews with 15 medical teachers. Study revealed that according to views of the medical students, factors like drug addiction $922(90.6 \%)$ \& student politics $835(82.0 \%)$ were negatively influencing academic performance of undergraduate medical students. On the other hand, factors like indoor-outdoor games 791(77.7\%), cultural activities $611(60.0 \%)$ \& social activities $658(64.7 \%)$ were positively influencing on their academic performance. Findings of the students' views were consistent with the teachers' views. In-depth interview of the teachers revealed that students should take part in extra-curricular activities alongside their study. But it should be in a balanced way so that they do not hamper their study. Teachers should encourage students to participate in extra-curricular activities. Study recommended that medical campus should be kept free from the unhealthy student politics. Study also recommended to prevent drug addiction, the parents should be aware \& the college authority should have adequate monitoring in the student hostels \& should strictly implement any measure if required.
\end{abstract}

Key words: Extracurricular activities, Influencing, Academic performance, Undergraduate medical students

1. Assistant Professor, Dept. of Pharmacology, City Dental College, Nikunjo, Dhaka.

2. Professor, Department of Community Medicine, Diabetic Association Medical College, Faridpur.

3. Professor, Curriculum Development \& Evaluation, Centre for Medical Education (CME), Mohakhali, Dhaka.

4. Assistant Professor, Dept. of Orthopedics, Medical College for Womens \& Hospital, Uttara, Dhaka.

5. Senior Lecturer, Dept. of Periodontology \& Oral Pathology, City Dental College, Nikunjo, Dhaka.

Address of correspondence: Dr. Arifa Begum, Assistant Professor, Dept. of Pharmacology, City Dental College, Nikunjo, Dhaka. Email: barifa2005@gmail.com

Bangladesh Journal of Medical Education 2020; 11(1); Begum et al., publisher and licensee Association for Medical Education. This is an Open Access article which permits unrestricted non-commercial use, provided the original work is properly cited. 


\section{Introduction}

Extracurricular activities are those activities performed by students that fall outside the realm of the normal curriculum of an institute. Extracurricular activities exist at all levels of education, from primary to university education. Such activities are generally voluntary as opposed to mandatory. This is done by students associations, student chapters \& individually. Students often organize \& direct these activities under faculty sponsorship \& supervision ${ }^{1,2}$.

Education is not solely learned by reading the textbook. Students can learn an incredible amount from their peers through extracurricular activities. Students learn how to compromise \& work in a group. Activities such as athletics, music, theater \& organizations teach students how to discipline themselves through drills, practices, or rehearsals. By participating \& persevering in any of these activities, the students gain a sense of self-respect, selfesteem \& self-confidence. Extracurricular activities give them pride in their accomplishments \& they learn that if an activity is worth doing, it is worth doing well. These team spirits are an excellent way to build character ${ }^{2-4}$.

Extracurricular activities are very helpful for physical \& mental fitness \& refreshment of the students. These are very useful to bring out latent talent of students. These also help students in personality development \& grow leadership among them. It provide additional field of knowledge beyond academic activities. A recent research demonstrate that extracurricular activities are also useful, effective in prevention of violence \& drug use among students if it is supervised by parents and teachers. Even that some educators felt that less desirable extracurricular activities were now distracting students from their curricular responsibilities. So there will be some rules $\&$ supervision of extracurricular activities so that it will be complimentary to education $^{5-9}$.

In most of the institutes extracurricular activities run throughout the year. Students engaged in extracurricular activities highly at the end of their examination when curricular activities are minimum. These are minimum when students are busy with their examinations \& preparation for examination. Like other institutes, medical students of Bangladesh they are also involved in a lot of extracurricular activities ${ }^{10}$.

Involvement in extracurricular activities may have provided students with additional opportunities that fostered the development of a lifelong commitment to a medical career. Balanced extracurricular activities or nonacademic experiences help extend an applicant's knowledge and development ${ }^{11}$. Findings of the research can be used for better policy decision for improvement of medical education of Bangladesh by promoting extracurricular activities which have positive impact on medical education $\&$ minimizing the unwanted extracurricular activities which have negative impact on medical education of Bangladesh; which will ensure better \& livery in Bangladesh ${ }^{12}$.

Bangladesh Journal of Medical Education 2020; 11(1); Begum et al., publisher and licensee Association for Medical Education. This is an Open Access article which permits unrestricted non-commercial use, provided the original work is properly cited. 


\section{Methodology}

This was a descriptive type of cross sectional study. The study period was July 2017 to June 2018 . The study was carried out among the four phases of the undergraduate medical students \& teachers of basic science, para clinical \& clinical subjects of four (04) government \& four (04) non-government medical colleges of Dhaka \& outside Dhaka. Medical colleges were selected purposively \& convenience sampling technique was adopted for data collection. Foreign students were excluded from the study. A pretested selfadministered semi-structured questionnaire having forty-three(43) close ended questions with two(2) open-ended questions using five points Likert scale were administered on 1020 students \& 58 teachers to collect data \& an in-depth interviews were conducted with 15 medical teachers. The study protocol $\&$ instruments were approved by the Institutional Review Board (IRB) of Center for Medical Education, Mahankali, Dhaka.

The researcher was introduced herself to the respondents (teachers and students) explaining the purpose $\&$ the procedure to be followed while filling up the questionnaire. They were assured so that they would not feel any hesitation to answer freely. Specific time was taken from the class teacher to collect data from the students. The students were free to either participate or not participate in the study.
The questionnaires were distributed to the students \& teachers to give their opinions or views. Students \& teachers gave the tick mark in the appropriate space on the questionnaire \& wrote their comments against the open-ended questions. After completion, the questionnaires were collected by the researcher $\&$ thanked them for their co-operation. Questionnaires from the teachers were collected according to teachers' convenience.

Questionnaires were edited after collection, coded manually \& numerical data were undergone processed \& analyzed by using SPSS version 16 computer software according to the objectives. For each variable frequency distribution \& mean score with SD was calculated. These data were presented in the form of tables, charts \& graphs with necessary descriptions. Qualitative data were presented in descriptive form.

Only those teachers agreed for sparing their time needed for in-depth interview were selected. Response of in-depth interviews were recorded by the researcher herself in a formatted paper. Interviews were recorded by a voice recorder subject to the consent of individual teacher. Contact number was taken after the interview \& necessary clarification was taken related to any obscured issues after preliminary analysis of the questionnaires.

Bangladesh Journal of Medical Education 2020; 11(1); Begum et al., publisher and licensee Association for Medical Education. This is an Open Access article which permits unrestricted non-commercial use, provided the original work is properly cited. 
Original Article

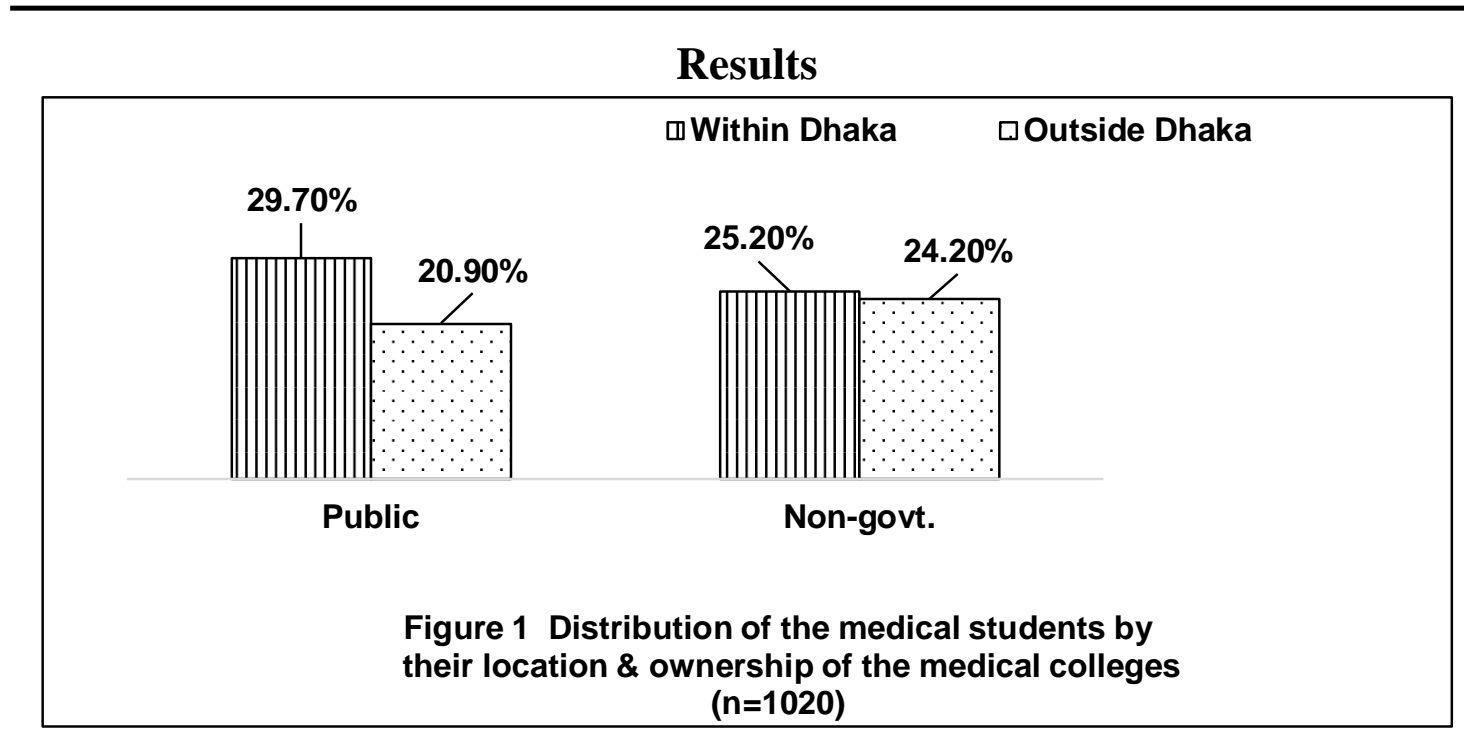

Figure 1 shows that out of 1020 medical students $516(50.6 \%)$ were studying in public medical colleges \& $504(49.4 \%)$ in non-government medical colleges. Of the medical colleges, $560(54.9 \%)$ located at Dhaka \& $460(45.1 \%)$ located outside Dhaka.

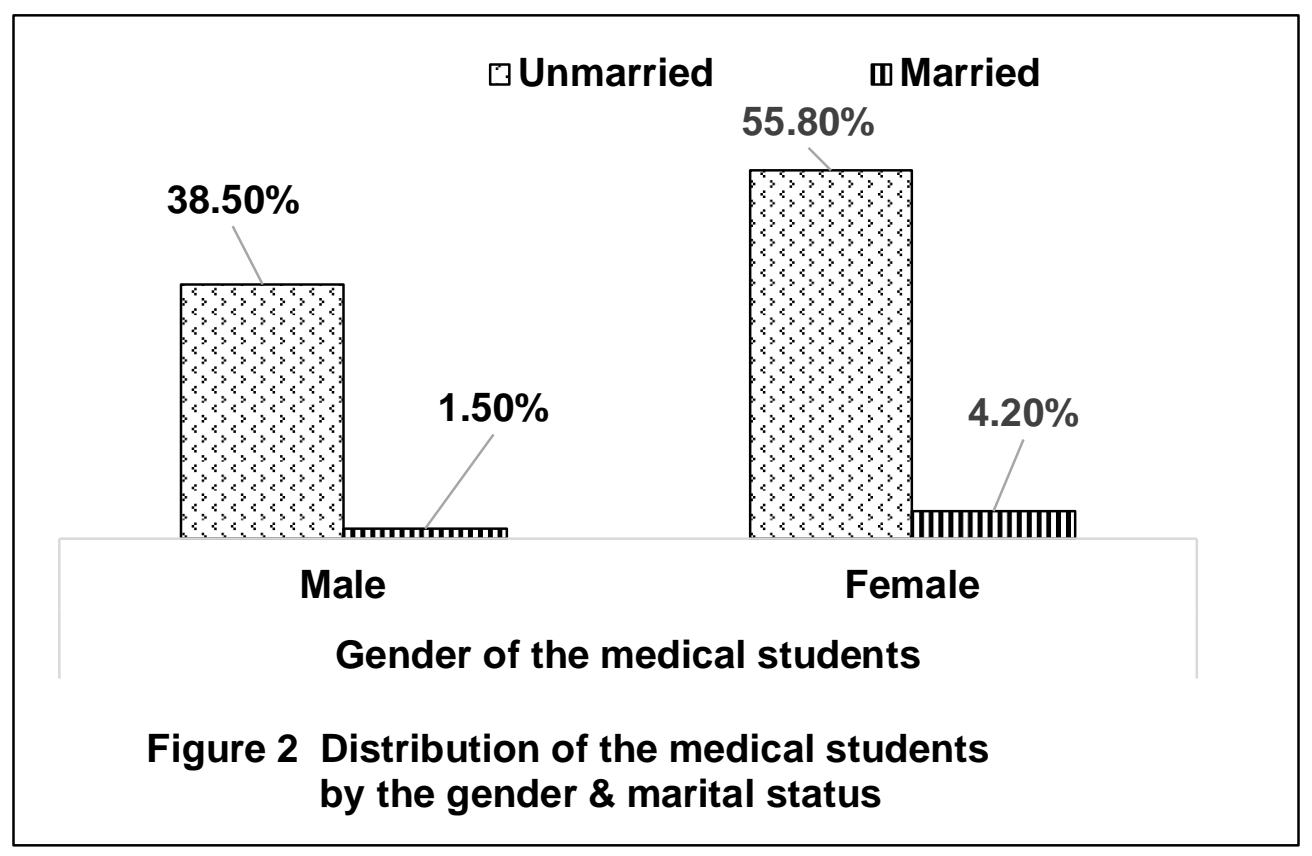

Figure 2 shows that out of 1020 medical students 408 (40.0\%) were male \& $612(60.0 \%)$ were female. Out of them $962(94.3 \%)$ were unmarried \& $58(5.7 \%)$ were married.

Bangladesh Journal of Medical Education 2020; 11(1); Begum et al., publisher and licensee Association for Medical Education. This is an Open Access article which permits unrestricted non-commercial use, provided the original work is properly cited. 
Original Article

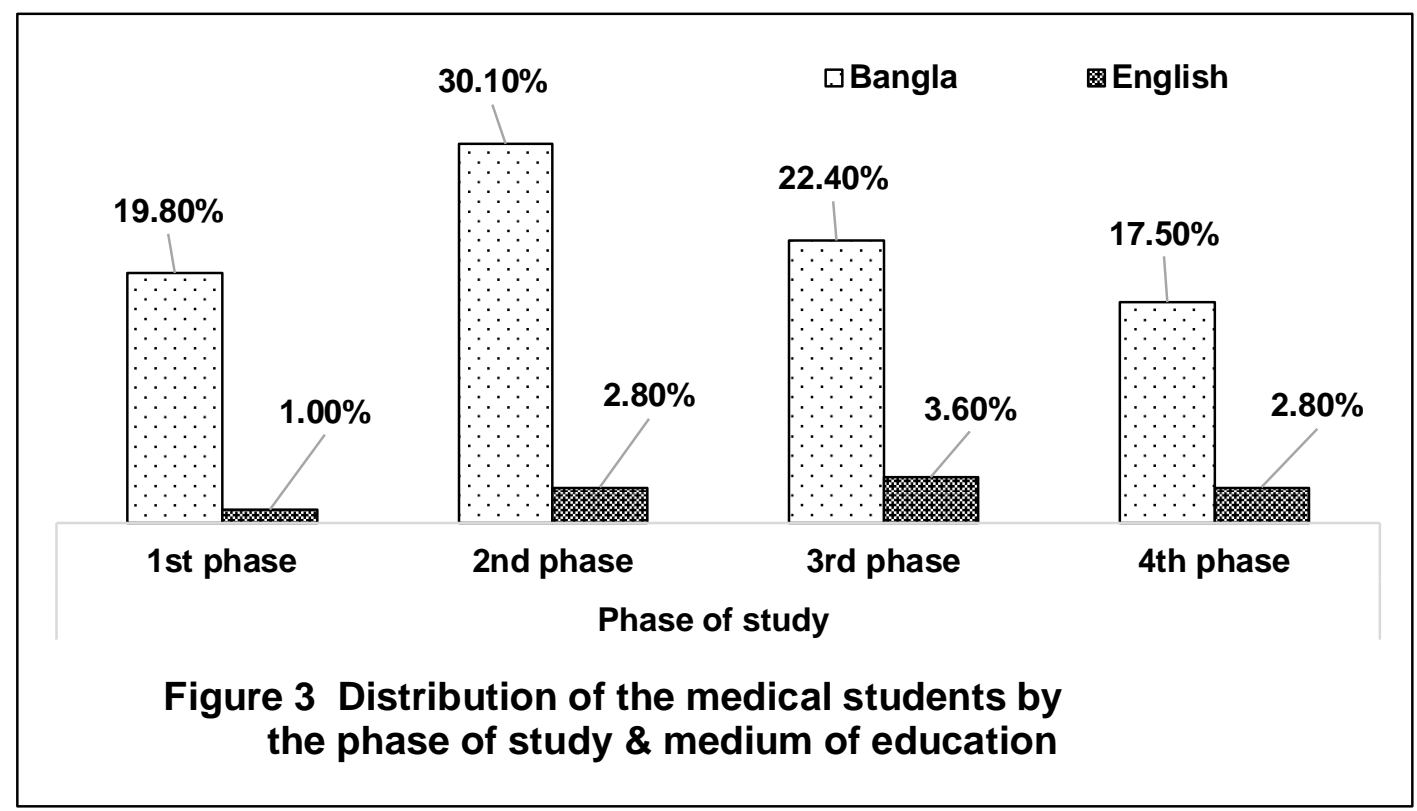

Figure 3 shows that out of 1020 medical students $212(20.8 \%)$ were in $1^{\text {st }}$ phase, 336(32.9\%) in $2^{\text {nd }}$ phase, $265(26.0 \%)$ in $3^{\text {rd }}$ phase $\& 207(20.3 \%)$ in $4^{\text {th }}$ phase. Out of them $915(89.7 \%)$ from Bangla medium \& 105 (10.3\%) from English medium.

Table 1 Distribution of the medical students by their opinion regarding the statements related to the extracurricular activities those influence their academic performance

\begin{tabular}{|c|c|c|c|c|c|c|}
\hline \multirow{2}{*}{ Statements } & \multicolumn{5}{|c|}{$\begin{array}{c}\text { Level of agreement } \\
\text { (with its corresponding score) }\end{array}$} & \multirow{2}{*}{$\begin{array}{l}\text { Mean } \\
( \pm \text { SD })\end{array}$} \\
\hline & $\begin{array}{l}\text { SDA(1) } \\
\text { f }(\%)\end{array}$ & $\begin{array}{c}\text { DA(2) } \\
\text { f }(\%) \\
\end{array}$ & $\begin{array}{c}\text { NAND(3) } \\
\text { f }(\%)\end{array}$ & $\begin{array}{c}\mathbf{A}(4) \\
\mathbf{f}(\%) \\
\end{array}$ & $\begin{array}{l}\text { SA(5) } \\
\text { f }(\%)\end{array}$ & \\
\hline $\begin{array}{l}\text { Too much involvement in } \\
\text { cultural activities hamper } \\
\text { performance }(n=1020)\end{array}$ & $78(7.6)$ & $331(32.5)$ & $217(21.3)$ & $293(28.7)$ & 101(9.9) & $\begin{array}{c}2.99 \\
( \pm 1.147)\end{array}$ \\
\hline $\begin{array}{l}\text { Students who are normally } \\
\text { involved in games (indoor and } \\
\text { outdoor) perform better } \\
(n=1018)\end{array}$ & $22(2.2)$ & $205(20.1)$ & $376(36.9)$ & $333(32.7)$ & $82(8.1)$ & $\begin{array}{c}3.24 \\
( \pm 0.937)\end{array}$ \\
\hline
\end{tabular}

Bangladesh Journal of Medical Education 2020; 11(1); Begum et al., publisher and licensee Association for Medical Education. This is an Open Access article which permits unrestricted non-commercial use, provided the original work is properly cited. 
Original Article

\begin{tabular}{|c|c|c|c|c|c|c|}
\hline $\begin{array}{l}\text { Excessive involvement in } \\
\text { social activities hampers } \\
\text { performance }(n=1016)\end{array}$ & $57(5.6)$ & $301(29.6)$ & $243(23.9)$ & $307(30.2)$ & $108(10.6)$ & $\begin{array}{c}2.89 \\
( \pm 1.113)\end{array}$ \\
\hline $\begin{array}{l}\text { Too much involvement in } \\
\text { student politics decreases } \\
\text { performance }(n=1019)\end{array}$ & $35(3.4)$ & $62(6.1)$ & $87(8.5)$ & $325(31.9)$ & $510(50.0)$ & $\begin{array}{c}1.81 \\
( \pm 1.050)\end{array}$ \\
\hline $\begin{array}{l}\text { Some of the cases love affair } \\
\text { decreases performance }(n=1019)\end{array}$ & $80(7.9)$ & $175(17.2)$ & $216(21.2)$ & $328(32.2)$ & $220(21.6)$ & $\begin{array}{c}2.58 \\
( \pm 1.222)\end{array}$ \\
\hline $\begin{array}{l}\text { Drug addiction hampers } \\
\text { performance }(n=1018)\end{array}$ & $41(4.0)$ & $29(2.8)$ & $26(2.6)$ & $183(18.0)$ & $739(72.6)$ & $\begin{array}{c}1.48 \\
( \pm 0.978)\end{array}$ \\
\hline Overall & 5.12 & 18.05 & 19.07 & 28.95 & 28.81 & $\begin{array}{c}2.49 \\
( \pm 1.255)\end{array}$ \\
\hline
\end{tabular}

NB: SDA= Strongly Disagree, $D A=$ Disagree, $N A N D=$ Neither agree nor disagree, $A=$ Agree, $S A=$ Strongly agree

Out of 1020 students, 922(90.6\%) and 835(81.9\%) were agreed that drug addiction and student politics negatively influence their academic performance. 548(53.8\%)were agreed that some of the cases love affair decreases performance. 415(40.8\%)\&394(38.6\%) students agreed that too much involvement in cultural \& social activities hamper their academic performance. 415 $(40.8 \%)$ were agreed that involved in games (indoor and outdoor) perform better The overall mean \& standard deviation of the statements were $2.49 \& 1.255$ (Table 1)

Table 2 Distribution of the medical teachers by their opinion regarding the statements related to the extracurricular activities those influence medical students' academic performance $(\mathbf{n}=58)$

\begin{tabular}{|c|c|c|c|c|c|c|}
\hline \multirow{2}{*}{ Statements } & \multicolumn{5}{|c|}{$\begin{array}{c}\text { Level of agreement } \\
\text { (with its corresponding score) }\end{array}$} & \multirow{2}{*}{$\begin{array}{l}\text { Mean } \\
( \pm \text { SD })\end{array}$} \\
\hline & $\begin{array}{l}\operatorname{SDA}(1) \\
\mathbf{f}(\%)\end{array}$ & $\begin{array}{l}\text { DA(2) } \\
\mathbf{f}(\%)\end{array}$ & $\begin{array}{l}\text { NAND(3) } \\
\mathbf{f}(\%)\end{array}$ & $\begin{array}{l}A(4) \\
f(\%)\end{array}$ & $\begin{array}{l}\text { SA (5) } \\
\text { f (\%) }\end{array}$ & \\
\hline $\begin{array}{l}\text { Too much involvement in cultural } \\
\text { activities hampers performance }\end{array}$ & $2(3.4)$ & $16(27.6)$ & $12(20.7)$ & $24(41.4)$ & $4(6.9)$ & $\begin{array}{c}2.79 \\
( \pm 1.039)\end{array}$ \\
\hline $\begin{array}{l}\text { Students who are normally } \\
\text { involved in games (indoor and } \\
\text { outdoor) perform better }\end{array}$ & $0(0)$ & $10(17.2)$ & $24(41.4)$ & $16(27.6)$ & $8(13.8)$ & $\begin{array}{c}3.38 \\
( \pm 0.933)\end{array}$ \\
\hline
\end{tabular}

Bangladesh Journal of Medical Education 2020; 11(1); Begum et al., publisher and licensee Association for Medical Education. This is an Open Access article which permits unrestricted non-commercial use, provided the original work is properly cited. 
Original Article

\begin{tabular}{lcccccc}
\hline $\begin{array}{l}\text { Excessive involvement in social } \\
\text { activities hampers performance }\end{array}$ & $0(0)$ & $16(27.6)$ & $15(25.9)$ & $23(39.7)$ & $4(6.9)$ & $\begin{array}{c}2.74 \\
( \pm 0.947)\end{array}$ \\
$\begin{array}{l}\text { Too much involvement in student } \\
\text { politics decreases performance }\end{array}$ & $0(0)$ & $3(5.2)$ & $2(3.4)$ & $19(32.8)$ & $34(58.6)$ & $\begin{array}{c}1.55 \\
( \pm 0.799)\end{array}$ \\
$\begin{array}{l}\text { Some of the cases love affair } \\
\text { decreases performance }\end{array}$ & $1(1.7)$ & $5(8.6)$ & $15(25.9)$ & $25(43.1)$ & $12(20.7)$ & 2.28 \\
$\begin{array}{l}\text { Drug addiction hampers } \\
\text { performance }\end{array}$ & $0(0)$ & $1(1.7)$ & $0(0)$ & $4(6.9)$ & $53(91.4)$ & $\begin{array}{c}1.12 \\
( \pm 0.951)\end{array}$ \\
Overall & & & & & & $\mathbf{2 . 3 6})$ \\
\hline
\end{tabular}

NB: $S D A=$ Strongly Disagree, $D A=$ Disagree, $N A N D=$ Neither agree nor disagree, $A=$ Agree, SA= Strongly agree

Out of 58 respondent teachers 57(98.3\%) \& 53(91.4\%) were agreed that drug addiction \& student politics negatively influence their academic performance. $37(63.8 \%)$ were agreed that some of the cases love affair decreases performance. $28(48.3 \%) \& 27(46.6 \%)$ respondent teachers agreed that too much involvement in cultural \& social activities hamper their academic performance.

$24(41.4 \%)$ were agreed that involved in games (indoor and outdoor) perform better. The overall mean \& standard deviation of the statements were $2.31 \& 1.162$ (Table 2)

Table 3 Comparing the medical students' and teachers' opinion regarding extracurricular activities those influence their academic performance

\begin{tabular}{lllll}
\hline Factor categories & $\begin{array}{l}\text { Respondents } \\
\text { number }\end{array}$ & Mean $( \pm$ SD) & t $($ df $)$ & $\begin{array}{l}\text { P value } \\
\text { (1-tailed) }\end{array}$ \\
\hline $\begin{array}{lllll}\text { Extracurricular } \\
\text { activities }\end{array}$ & \begin{tabular}{lll} 
Student $(\mathrm{n}=1020)$ \\
\cline { 2 - 3 }
\end{tabular} & $2.49( \pm 0.560)$ & $6.896(76.507) *$ & 0.000 \\
\hline
\end{tabular}

*Welch t test was apply

Table 3 compared the mean scores of students' \& teachers' opinion regarding extracurricular activities those influence the academic performance of the students. It was observed that the mean scores of students were higher than the corresponding mean scores of teachers. These difference was statistically significant $(\mathrm{p}<0.05)$.

Bangladesh Journal of Medical Education 2020; 11(1); Begum et al., publisher and licensee Association for Medical Education. This is an Open Access article which permits unrestricted non-commercial use, provided the original work is properly cited. 
Original Article

Table 4 Comparing the medical students' opinion by their gender \& medium of schooling regarding extracurricular activities those influence their academic performance

\begin{tabular}{|c|c|c|c|c|}
\hline Factor categories & $\begin{array}{l}\text { Respondents } \\
\text { number }\end{array}$ & Mean $( \pm$ SD) & $\mathbf{t}(\mathbf{d f})$ & $\begin{array}{l}\text { P value } \\
\text { (1-tailed) }\end{array}$ \\
\hline \multirow{4}{*}{$\begin{array}{l}\text { Extracurricular } \\
\text { activities }\end{array}$} & $\operatorname{Male}(n=408)$ & $2.50( \pm 0.625)$ & \multirow{2}{*}{$0.63(753.449) *$} & \multirow{2}{*}{0.475} \\
\hline & Female $(n=612)$ & $2.49( \pm 0.513)$ & & \\
\hline & Bangla $(n=915)$ & $2.48( \pm 0.558)$ & \multirow{2}{*}{$-2.500(1018)$} & \multirow{2}{*}{0.007} \\
\hline & English $(\mathrm{n}=105)$ & $2.63( \pm 0.566)$ & & \\
\hline
\end{tabular}

*Welch t test was apply

Table 4 compared the mean scores of male \& female students' opinion \& Bangla \& English medium students' opinion regarding extracurricular activities those influence their academic performance. It was observed that the mean scores of male were higher than the corresponding mean scores of female. These difference was statistically not significant $(\mathrm{p}>0.05)$. On the other hand, the mean scores of English medium were higher than the corresponding mean scores of Bangla medium. These difference was statistically significant $(\mathrm{p}<0.05)$

There were some open-ended questions to specify the reasons behind their answer. The answers to the open-ended questions were very much diverse. The response was grouped. Students mentioned several factors like healthy campus, relaxation time, study tour, cultural programme, annual picnic, recreation, proper use of audiovisual aids, available medical related journal/video, practical/clinical based learning, available patients in the hospital, well established library facilities, developed canteen facilities, arrange indoor-outdoor games, communication with the parents/guardian, good teacherstudent relationship were positively influencing.

Students also mentioned about improper subject distribution in $2^{\text {nd }} \& 3^{\text {rd }}$ phases, lack of administrative \& academic supervision, political activities of some teachers \& students, poor residential facilities for students, uncomfortable hostel environment, unhealthy dining meal, drug abuse among students, less responsibility of teachers, \& senior-junior bad relationship were negatively influencing.

Some suggestions were given by the students. Student politics should be stopped. Political activities in the institute by the students as well as by teachers should be prohibited or at least it should be minimized. Sufficient equipment, scope, time should be available for extracurricular activities. Hostel facilities should be adequate.

In-depth interview of the teachers revealed that students should take part in extra-

Bangladesh Journal of Medical Education 2020; 11(1); Begum et al., publisher and licensee Association for Medical Education. This is an Open Access article which permits unrestricted non-commercial use, provided the original work is properly cited. 
curricular activities alongside their study. But it should be in a balanced way so that they do not hamper their study. Teachers should encourage students to participate in extra-curricular activities. The educational institution should provide well established library, IT facilities, common room \& sports facilities.

\section{Discussion}

The students were involved in several extracurricular activities like voluntary \& charity works, organizing committees, sports, clubs, debate, drama, school publications, student council \& other social events \& offer real-world experience \& understandings that are not counted in the formal course of study. Much of the students $(56.3 \%)$ were involved 1-2 events per year \& at least $5 \mathrm{~h} /$ week. Much of the students $(63.2 \%)$ attended $<4$ medical conferences \& seminars per year \& $15.8 \%$ did not attend any conferences \& seminars. Approximately $45 \%$ spent some time every day outside the University for socialization. It has recommended that 'having a regular hobby and enjoying a normal social life does not significantly affect academic performance, ${ }^{13}$.

Except few, majorities of the respondents were in disfavor of political activities in their medical colleges as it hamper academic activities $^{12}$.

In another study ${ }^{14}$ showed that female students participated significantly more than males in medical volunteer or community service, club activities \& research than males. Females spent significantly more medical volunteer time than did males, while males \& females spent similar nonmedical volunteer hours ${ }^{14}$. Females reported participating in significantly greater numbers of overseas volunteer experiences than males ${ }^{11}$.

\section{Conclusion}

In this study, according to the views' of the teachers \& students, the extracurricular activities like social (donating or arranging blood or medicine, volunteer \& charity work, organizing committees etc.), cultural (debate competitions, annual picnic, magazine etc.) activities, indoor-outdoor games were positively influence medical students' academic performance. But too much involvement hampers their academic performance. On the other hand, drug addiction, too much involvement in student politics, some of the cases love affair were negatively influencing on academic performance of the undergraduate medical students. If the above mentioned all positive factors will be implemented \& all negative factors will be eliminated, then students' academic performance will be improved.

\section{Recommendation}

1. The hostel \& college environment should be improved with adequate facilities for recreation, games, cultural

Bangladesh Journal of Medical Education 2020; 11(1); Begum et al., publisher and licensee Association for Medical Education. This is an Open Access article which permits unrestricted non-commercial use, provided the original work is properly cited. 
environment, scope for creative work etc. which keep students cheerful.

2. Medical campus, hospitals \& hostels should be kept free from the unhealthy student politics.

3. For prevention of drug addiction, the parents should be aware \& the college authority should have adequate monitoring in the student hostels \& should strictly implement any measure if required.

4. Further qualitative in depth interview, focus group discussion \& large scale of quantitative study is recommended to generalize the findings.

\section{Acknowledgement}

Authors are much grateful to those faculty members who participated in this study. Moreover, authors like to extend their heartfelt thanks to the principals of selected 8 medical colleges of Bangladesh for their kind cooperation to conduct the study.

\section{References}

1. Curricular and extracurricular activities of medical students during war, Zagreb University School of Medicine, 19911995. Acad. Med. 2001; 76:82-87

2. Toward Curriculum Improvement: Cooperative Curriculum Development: A Symposium: The Role of Pupils in Cooperative Curriculum Development by Teachers College Department of Curriculum and Teaching - 1949
3. Adam Gamoran 1997, Curriculum Change as a Reform Strategy: Lessons from the United States and Scotland

4. Curriculum and Aims \& Curriculum: Perspective, Paradigm, and Possibility reviewed by Michael W. Apple \& Ralph Tyler - 1987

5. The Curriculum of the Elementary School: The Curriculum of the Horace Mann Elementary School by Samuel T Dutton \& Henry C. Pearson -1904

6. Perry CL, Komro KA, VeblenMortenson S. A Randomized controlled trial of the middle and junior high school D.A.R.E. and D.A.R.E. Plus programs. Arch PediatrAdolesc Med. 2003; 157: 178-184.

7. Basic Principles of Curriculum and Instruction. Ralph W.Tyler. University of Chicago Press, Cicago.

8. A curriculum for life: School for a demographic Society. John Quike. Open University Press, Philadelphia.

9. Curriculum Design. Edited by Michal Golby, Jane Greenwald Ruth West. Open University Press, London.

10. Curriculum Innovation: A celebration of classroom practice. Rogern Crombie White. Open University Press, Philadelphia.

Bangladesh Journal of Medical Education 2020; 11(1); Begum et al., publisher and licensee Association for Medical Education. This is an Open Access article which permits unrestricted non-commercial use, provided the original work is properly cited. 
Original Article

11. Kim S Extracurricular activities of medical school applicants. Korean Journal Medical Education 2016 Jun; 28(2): 201-207

12. Talukder MHK, Faruque M, Alam $\mathrm{K} \mathrm{K}$, Nargis T, Hussain SMA, Hossain MZ, Nazneen R, Rahman MZ. Evaluation of impact of existing extracurricular activities at Undergraduate Medical and Dental education in Bangladesh. Bangladesh Medical Journal; 2008; 37(1):6-9.

13. Haque M, Rahman NA, Majumder MA, Rahman NA, Haque SZ,
Zulkifli Z,Lugova H, Musa RM,Alattraqchi AG,. Assessment of academic/nonacademic factors and extracurricular activities influencing performance of medical students of faculty of medicine, University Sultan Zainal Abidin, Malaysia. Advances in Human Biology 2018; 8:3-18

14. Massoni, Erin. Positive Effects of Extra Curricular Activities on Students, ESSAI 2011;Vol. 9, Article 27:84-87

Bangladesh Journal of Medical Education 2020; 11(1); Begum et al., publisher and licensee Association for Medical Education. This is an Open Access article which permits unrestricted non-commercial use, provided the original work is properly cited. 